Volume 10, No.3, May - June 2021

International Journal of Advanced Trends in Computer Science and Engineering

Available Online at http://www.warse.org/IJATCSE/static/pdf/file/ijatcse1531032021.pdf

https://doi.org/10.30534/ijatcse/2021/154032021

\title{
A Study on Use of WhatsApp Messenger among Students for their Academic Achievements: A Case Study
}

\author{
Zeeshan Ali Rahu ${ }^{1}$ Hina Bhanbhro ${ }^{2}$ Rozina Chohan ${ }^{3}$ Hosh Muhammad ${ }^{4}$ \\ ${ }^{1}$ Department of English, Shaheed Benazir Bhutto University, Sanghar Campus, Sindh, Pakistan \\ rahuzeeshan@gmail.com \\ ${ }^{2}$ Shaheed Benazir Bhutto University, Shaheed Benzirabad, Sindh, Pakistan \\ Hina@ sbbusba.edu.pk \\ ${ }^{3}$ Department of Computer science, Salu, Khairpur Miras, Sindh, Pakistan, \\ Rozinachohan@yahoo.com \\ ${ }^{4}$ Lecturer (Islamic Studies) SBBUSBA. \\ hoshbaloch@sbbusba.edu.pk
}

\begin{abstract}
Today's world technology plays a crucial role and rapid development of internet help the growing of messages processing using digital devices. These movements leading us towards the connecting and maintaining the relationships. This paper aims to investigate WhatsApp usage among students. The theoretical framework for current study is the "Uses and Gratifications theory", is called "Needs and Gratifications Theory". The current study covers qualitative feature of the research. This segment pact with examination of the usage of WhatsApp in everyday survives for students. The detailed meetings of 8 energetic WhatsApp users, three boys and five girls of the university were directed. As the students are the male student their explanation is to some extent is same they revealed that, they use WhatsApp application for the calls purpose and for sending notes and online study purpose. They use Facebook messenger for the purpose of joining different sort of study circle pages and for informal purpose.
\end{abstract}

Key words: WhatsApp, learning, E-Learning, Social media, Needs and Gratifications Theory.

\section{INTRODUCTION}

Undoubtedly, a rapid growth of technology has tremendously helped the people to use their social media accounts easily. Around the globe, now, the social media has been surfing by the people with different ways. They visit the globe sooner than later. Every institution, organization, corporation and industry, across the globe, has been introducing itself by technology for a good deal of time. (Hussain, Z., Mahesar, R.,
Shah,2017). Technology is now being utilized within these rostrums. Social media comprises many of its types as Facebook, WhatsApp, LinkedIn, Twitter, Yahoo, Gmail, Hotmail, Skype, Messenger and many others too. These all the social media tools help people in many purposes like sharing the videos and pictures, chatting for different purposes getting in touch with news and updates and teaching as well as learning at most. In today's world technology plays a crucial role for the language learners. With the rapid development of Internet, Immediate Messaging (IM) facilities maintained by numerous Digital devices are conveying blast of connections among users. These all are leading us towards the connecting and maintaining the relationships. The beginning of Instant Mobile Messaging applications is firming the passion of social associations. According to Global Messaging Results, WhatsApp is utmost used messaging service in United Kingdom with 59\%. Since last couple of years there has been fast growth in online communication, particularly in mobile communication as $69 \%$ of all the users of Internet did so by the mobile device. In current years, the latest technology of mobile phone application reformed number of radical variations transferred from communication of interpersonal device to software groups. Previous, only for the purpose of making calls all people used to use mobile phones, for the purpose of sorting information like as, calendars and contacts, personal computers achieved tasks such as, reading emails, accessing the internet, playing games and editing documents as well. (Kumar, N., \& Sharma, S. 2016). The classes is on the basis of the student and as well teacher appearance whereas the amount of time is reduced. In this method of learning the participants can learn and apply the practical work in lab whereas adding some online aspect can reduced the efforts. It can enhance the time which provided online learning process and reduced being physically appeared in class. The fact to face communication and class activities can improve the teacher and student understanding whereas online aspect provide students facility over distance which is important in these days. One can easily combine the process of the fact to 
face insertion learning and having online features of the information sharing with some online easy mechanism.

According to (Costa-Sanchez, C, 2020) learners can easily enjoy the face to face communication meeting with the teacher as well having some flavor of the online management system which can provide the students ease of the usage having some relaxation. Nowadays this world is known as a global era, so in this situation everyone wants to connect with each other because of different purpose for international business ,education, politics ,international computer communication and internet, sports, technology due to sharing information with each other. Therefore, it is need of international inhabitants who wants to communicate with each other for different purposes and they want to be associated and communicate and want to share their ideas. They keenly corporate with each other for their different daily routine purposes, so for that reason they want a special and international and global language for mutual communication which is equally and universally accepted with global citizen .It is a renowned proverb that "Necessity is the mother of invention". According to Anne Johnson in "The rise of English", (cited in Macalester international vol.22, p.131).The English language is an international language because 380 million people communicate in English as their native language or first language and $2 / 3$ people use it as a second language in the world. According to Fauzia Shamim that the English is became a lingua franca and it plays a vital role for the development of socio-economic development, educational, politics, international computer communication and internet,sports, technology and sharing information about different purpose and build up mutual association. No doubt number of people are also still associated with each other due to English language communication. There are number of teaching method arts introduces in $20^{\text {th }}$ century but recent three to four decades communication language teaching has been gain an impressive and attractive insight during second or foreign language teaching in classrooms in the world (Kavanagh.B,2012). CLT is concerned with sociolinguistic. It emphases on activity based learning and engage the students with proper, authentic and meaningful use of language at classroom.

\subsection{BACKGROUND HISTORY OF WHATSAPP}

The origin of the word "WhatsApp" is "what's up" an English phrase. Its meaning is something new that is usually asked as to what is update. WhatsApp, as an electronic device-cum-chat application being used with discrepant types of programs was set up in 2009 by two ex-Yahoo employees Brian Acton and Jan Koum. It is an instant messaging application which offers the users surfing Internet connection, having an access to share videos, audio, images and written messages as well. The inexpensiveness of this application places WhatsApp as a great and cheap alternative to Short Message Service (SMS) messaging, which can remarkably be expensive when it is used outside one's country because of the wandering charges; the online interaction made immediate by WhatsApp instant messaging promotes combined mobile learning. Learners can easily share data and news and updates, have their own queries being quickly replied, increase the knowledge and produce class involvement via WhatsApp instant messaging. Mixed learning can highly be prompted by the WhatsApp instant messages.

\subsection{WHATSAPP APPLICATIONS}

This kind of cheap application has its variety of the functions; it persuades the learners to learn more and more, it encourages the students to have communication with their peers, it conveys the new and fresh information, it also arranges the class, it makes students able to be updated, it saves the time in a good deal, and strengthens the efficiency by recalling the students as to what to do and what they want to carry to class.

\subsection{OBJECTIVES}

- To determine the extent of WhatsApp use among students.

- To know the reasons of WhatsApp use among students.

- To determine the impact of WhatsApp on students' studies.

\subsection{RESEARCH QUESTIONS}

- What is the level of WhatsApp use among students?

- Why do the students use WhatsApp?

- Does WhatsApp have the impacts on students' studies?

\subsection{HYPOTHESIS}

- The Intensity of usage of WhatsApp messenger is very high among students because of its cheap cost.

- WhatsApp messenger has negative impact on youth.

\section{LITERATURE REVIEW}

Now the social networking sites have billions or even uncountable users across the globe. The sites have made the world as a global village where all and sundry has an easy access to their neighbors in getting in touch with one another. Social networking sites, now, has named the world with integrated vehicle one. The advancement in technology has carried a tremendous popularity and growth in social networking sites which have derived the concerns within communication experts, school authorities and socio-psychological researchers towards the advantages and heavy risks to which undergraduates are facing, as they make them busy in online social networking to fill their information and social needs rather than they reach one another physically and have one to one communication. Pouring further the light over the dangers of social networking sites on verbal communication into their users, Sherry Turkle (2012), the founder and director of the MIT initiative on technology and 
self, has argued that the easiness towards the social networking sites provides the users with access to communicate with one another can detriment their interpersonal communication. Also, social networking sites have enabled people to see one another as objects before them.

Study 1: Social Media's gratifications and uses: A contrast of Facebook and Instant Messaging. The study directed by (Haase and Young, 2010) specified that crucial inspirations of connecting social media is social associations, noble burden, and practical necessity that inspires users to use social media. The study also recognized the influences of inspirations: problem sharing, Passing time, Friendliness, Style, Sociability, Information about society. The above study determined that above factors were the motives of using Facebook instead of instant messaging by youth students dropping in the age group of 20 to 24 years.

Study 2: WhatsApp or Whats up? Associating Mobile Instant Messaging activities with Old (SMS). Another study was directed by (Karen Church, Rodrigo de oliveira, 2013) described 8 main ideas through interview of 9 energetic users of WhatsApp and more verified through review of 131 youth of Spain by online surveys. These themes were: Community Inspiration, Charge, Intent/ Nature, Public \& Discretion anxieties, sense of association, Proximity, \& Opportunities, Consistency \& Assurance, Coping Mechanism, Choice of technology. The study determined that claims got admiration due to economic motives Because of its nature as it is suitable tiny difficult and to use.

\subsection{THEORETICAL FRAMEWORK}

The theoretical framework for current study is the "Uses and Gratifications theory", is called "Needs and Gratifications Theory". This theory deals the media of audience usage and the satisfaction it gathers from the action in a technically satisfactory way. This theory emphasis on what persons do with media moderately and what media do with individuals. According to (Katz, Blumler, and Gurevitch ,1973-1974) who well-defined the theoretic substance as under:

1. The mental and social derivation

2. Desires which cause

3. Opportunities of

4. The other sources or mass media, that tend to

5. Variance forms of experience of media (or assignation in extra events), subsequent

6. Necessity gratifications

7. Additional significances, possibly frequently in different ones.

8. Abraham Maslow suggested five groups of necessity that persons are inspired to gratify, and they impose to everybody. The needs of Hierarchy are as below:

(a.) Physical desires (water, air, food).

(b.) Needs of safety (refuge, firmness, and liberty from danger or anxiety).

(c.) Needs of social (affection, friendship, reception, and communication with individuals). (d.) Reverence needs (individual feelings of attainment or self-confidence and need for gratitude or admiration from individuals).

(e.) Self-actualization (self-fulfillment or understanding of one's probable) - develop everything that someone is skilled of becoming.

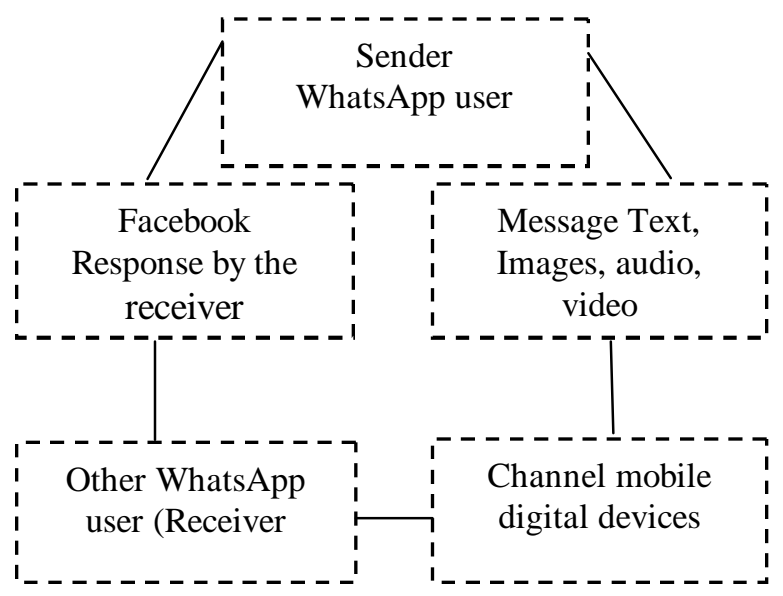

Figure :1 Social Media's gratifications and uses

\section{METHODOLOGY}

3.1 Location Period: The study involves of one phase. Section of interviews was directed from "September to February 12, 2019". However, investigation was directed from "September to December, 2019".

\section{ANALYSIS}

\begin{tabular}{|l|l|}
\hline Gender & Frequency \\
\hline Male & 44 \\
\hline Female & 56 \\
\hline Age & Frequency \\
\hline 18 to 20 & 20 \\
\hline 21 to 22 & 64 \\
\hline 23 to 24 & 16 \\
\hline $\begin{array}{l}\text { Purpose of using } \\
\text { WhatsApp }\end{array}$ & Frequency \\
\hline For news and updates & 25 \\
\hline For chat & 26 \\
\hline For class activities & 36 \\
\hline Others & 13 \\
\hline $\begin{array}{l}\text { Time consumption in } \\
\text { WhatsApp }\end{array}$ & Frequency \\
\hline Below 3 hours & 49 \\
\hline Between 4 \& 5 hours & 26 \\
\hline More than 5 hours & 25 \\
\hline $\begin{array}{l}\text { Use of WhatsApp } \\
\text { during class }\end{array}$ & Frequency \\
\hline
\end{tabular}




\begin{tabular}{|l|l|}
\hline Yes & 21 \\
\hline No & 54 \\
\hline Sometimes & 25 \\
\hline $\begin{array}{l}\text { Member of group on } \\
\text { WhatsApp for academic } \\
\text { activities }\end{array}$ & Frequency \\
\hline Yes & 90 \\
\hline No & 10 \\
\hline $\begin{array}{l}\text { Sharing of class work } \\
\text { assignments with } \\
\text { friends }\end{array}$ & Frequency \\
\hline Yes & 70 \\
\hline No & 5 \\
\hline Sometimes & 25 \\
\hline $\begin{array}{l}\text { Effects of WhatsApp on } \\
\text { studies }\end{array}$ & Frequency \\
\hline Negative & 33 \\
\hline Positive & 57 \\
\hline No idea & 10 \\
\hline
\end{tabular}

Table :1 Analysis of data

\section{CONCLUSION}

This study exposed considerable facts concerning students and WhatsApp. Therefore, WhatsApp is much quicker and more convenient way to interact with people which boosts up the effective flow of massages and ideas among students. No doubt, intensity of WhatsApp is very high among students (of the respective university) because it cuts the calling and SMS costs. Therefore, its primary objective and hypothesis obviously accepted. WhatsApp brought eases of content usage and management with fast and rapid output based learning. The incorporation of ICT tools and techniques could bring more changes and saves time energy to control and coordinate the activities of the course teaching in higher institutes. This application is important to focus due to ease of usability and management of course online and several new trends and techniques. Researchers are making most of it to focus on other applications as well for the improvement and enhancement of the integrity and rapid communication of the participants. Apart from it students revealed their explanation is to some extent is same they revealed that, they use WhatsApp application for the calls purpose and for sending notes and online study purpose. They use Facebook messenger for the purpose of joining different sort of study circle pages and for informal purpose.

\section{RECOMMENDATIONS}

Time should be managed for social media use. Social life is prior to social media use. People should focus on their living standards connected with time to be managed. Pakistan Telecommunication Authority (PTA) should reduce their calling and SMS rates thereby for decreasing the usage of WhatsApp. People should try to access WhatsApp through Wi-Fi but do not use it every time. For it the connectivity can be available on college. Then it will helpful to reduce addiction.

\section{REFERENCES}

[1] Buchenscheit, B. Konings, and A. Neubert, (2014). "Privacy Implications of Presence Sharing in Mobile Messaging Applications," Proceedings of the 13th International Conference on Mobile and Ubiquitous Multimedia., 20-21.

[2] Costa-Sánchez, C., \& Guerrero-Pico, M. (2020). What is WhatsApp for? Developing transmedia skills and informal learning strategies through the use of whatsapp —a case study with teenagers from spain. Social Media+ Society, 6(3), 2056305120942886.

[3] Ham, Y.J,et. al., (2014). "Android Mobile Application System Call Event Pattern Analysis for Determination of Malicious Attack", International Journal of Security and Its Applications., 8(1), 231-246.

[4] Hussain, Z., Mahesar, R \& Memon, N. A. (2017). WhatsApp usage frequency by university students: A case study of Sindh University. Engineering Science and Technology International Research Journal, 1(4), 15-45.

[5] Ibrahim.I. Ima, et.al. (2013). "Antecedent Stirring Purchase Intention of Smartphone among Adolescents in Perlis", International Journal of Academic Research in Business and Social Sciences., 3(12).

[6] Kaplan and Haenlein, (2010). "Users of the world, unite! The challenges and opportunities of Social Media", Business horizons., 53, 59-68 .

[7] M. Mallick, (2003). "Mobile and Wireless Messaging," in Mobile and wireless Design Essentials. Indiana, Canada: Wiley, Ch., 5, 117-118 .

[8] Mahajan.A,, Dahiya, (2013). "Forensic Analysis of Instant Messenger Applications on Android Devices", International journal of computer applications., 68(8).

[9] S. Lauricella\& R. Kay, (2013). "Exploring the use of text and instant messaging in higher education classrooms," Research in Learning technology., 21, 2.

[10] The Times of India, (2014). "Facebook to pay \$19bn to buy WhatsApp", Times of India., 12 